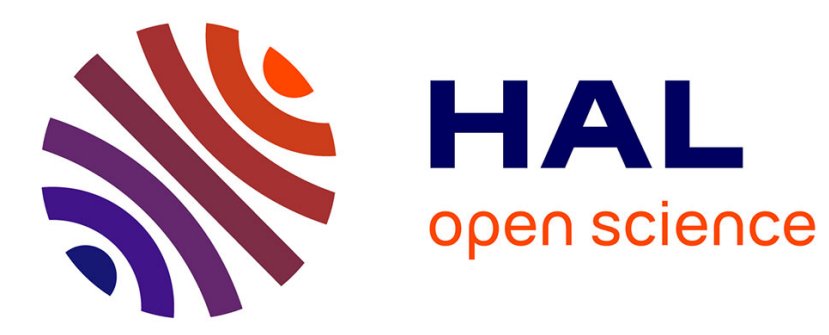

\title{
Fusarium-wilt suppressive soils from the Châteaurenard region : review of a 10-year study
}

Claude Alabouvette

\section{To cite this version:}

Claude Alabouvette. Fusarium-wilt suppressive soils from the Châteaurenard region: review of a 10-year study. Agronomie, 1986, 6 (3), pp.273-284. hal-00884876

\section{HAL Id: hal-00884876 https://hal.science/hal-00884876}

Submitted on 1 Jan 1986

HAL is a multi-disciplinary open access archive for the deposit and dissemination of scientific research documents, whether they are published or not. The documents may come from teaching and research institutions in France or abroad, or from public or private research centers.
L'archive ouverte pluridisciplinaire HAL, est destinée au dépôt et à la diffusion de documents scientifiques de niveau recherche, publiés ou non, émanant des établissements d'enseignement et de recherche français ou étrangers, des laboratoires publics ou privés. 


\title{
Fusarium-wilt suppressive soils from the Châ- teaurenard region : review of a 10-year study
}

\author{
Claude ALABOUVETTE \\ I.N.R.A., Station de Recherches sur la Flore pathogène dans le Sol, 17 rue Sully, F 21034 Dijon Cedex
}

This paper presents the main results obtained while studying the fusarium-wilt suppressiveness of Châteaurenard soil. Experimental data are discussed in relation to the main theories developed to explain the phenomena of soil suppressiveness to fusarium wilts. This suppressiveness, based fundamentally on microbiological interactions, relies on the complementary association of a general mechanism of competition for nutrients between the whole soil microflora and the entire Fusarium population and intrageneric competition between pathogenic and non-pathogenic Fusarium. This research has led to new approaches for microbiological control of fusarium wilts.

Additional key words : soil receptivity, competition for nutrients, general suppression, specific suppression, biological control.

La résistance des sols de Châteaurenard aux fusarioses vasculaires: bilan de 10 années de recherche.

\begin{abstract}
Cet article présente de manière synthétique les résultats auxquels ont donné lieu les recherches consacrées à la résistance des sols de Châteaurenard aux fusarioses vasculaires. Les résultats expérimentaux sont discutés par rapport aux principales théories développées pour expliquer les phénomènes de résistance des sols aux fusarioses vasculaires. Cette résistance, de nature fondamentalement microbiologique, repose sur l'association complémentaire d'un mécanisme général de compétition nutritive entre l'ensemble de la microflore tellurique et la population fusarienne et d'un mécanisme spécifique de compétition intragénérique entre formes pathogènes et non pathogènes de Fusarium. Ces recherches suggèrent de nouvelles voies pour élaborer des procédés de lutte microbiologique contre les fusarioses vasculaires.
\end{abstract}

Mots clés additionnels : réceptivité des sols, compétition nutritive, résistance générale, résistance spécifique, lutte biologique.

\section{INTRODUCTION}

In recent years, research on disease-suppressive soils has been widely developed (SCHNEIDER, 1982). Various models have been examined for the major diseases caused by soil-borne pathogens, including damping-off, root rots, and vascular wilts. A large number of publications on fusarium-wilt suppressive soils propose diverse, if not contradictory, interpretations. It is clear, however, that suppressiveness is based on complex and poorly understood microbiological mechanisms (COOK \& BAKER, 1983). It would therefore be premature to confront the various theories available if, as indicated by the results of our study of Châteaurenard soils (Bouches-du-Rhône, France), suppressiveness may involve more than one mechanism. The purpose of this paper is to review the results obtained by our laboratory $\left({ }^{*}\right)$ while studying fusarium-wilt suppressive soils from the Châteaurenard region (ALABOUVETTE et al., 1979 ; LOUVET et al., 1981 ; ALABOUVETTE et al., 1985a). These results are discussed in relation to the methods used and to the major conclusions drawn from all the research devoted to suppressive soils and microbial interactions in soil environment. Finally, we indicate on the basis of these past studies, the orientation of future disease control research to be considered, hoping that feasible microbiological methods for controlling fusarium wilt will be developed soon.

\footnotetext{
* This review is based on original data obtained by C. ALABOU vette, Y. Coutealdier, J. Louvet and F. Rouxel. This is why the author employs the plural while speaking of the hypotheses and
} results. 
II. DISEASE-SUPPRESSIVE AND DISEASECONDUCTIVE SOILS : TWO CHARACTERISTIC LEVELS OF SOIL RECEPTIVITY

Soil receptivity to soil-borne pathogens reflects the capacity of a soil to allow a pathogen to establish, develop, persist, and express its pathogenicity on host plants (AL.ABOUVETTE et al., 1982). A disease-suppressive soil is one in which disease severity remains limited in spite of a high pathogen inoculum density. A disease-conducive soil allows severe disease in the presence of a relatively low pathogen inoculum density.

The concept of soil receptivity to disease was coined as we started working on fusarium-wilt suppressive soils. For many years, we only investigated soils in which disease occurred, all other soils being regarded as not infested with the pathogen. Then, we realized that the absence of disease could not always be accounted for by the absence of the pathogen, e.g. Fusarium oxysporum $\mathrm{f}$. sp. melonis, cause of fusarium wilt of melons, could be found in Châteaurenard soils without causing wilt. Soil can therefore limit, to some degree, disease expression. This can easily be demonstrated by introducing into various soils increasing amounts of a given pathogen ; at similar inoculum densities, severity of disease on a population of susceptible host plants varies significantly according to soils (fig. 1), indicating the various degrees of soil receptivity to fusarium wilt (ALABOUVETTE et al., 1982). It is thus possible to identify disease-suppressive

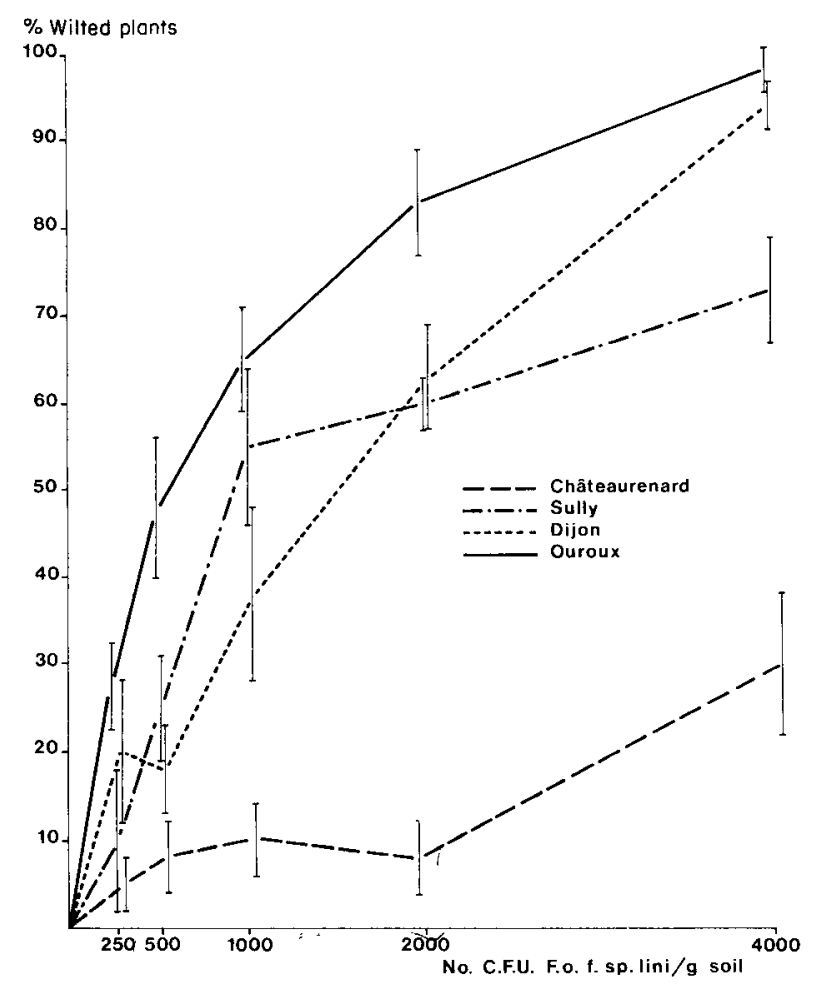

Figure 1

Receptivity of 4 soils to fusarium wilt of flax : percentage of wilted plants 4 weeks after soil infestation with $\mathrm{F}$. o. $f$. sp. lini at increasing concentrations. Mean of 12 replicates of 5 plants with its standard deviation.

Réceptivité de 4 sols à la fusariose vasculaire du lin : pourcentage de plantes mortes 4 semaines après infestation des sols par des doses croissantes de F. o.f. sp. lini. Moyennes de 12 répétitions de 5 plantes avec leurs écarts-type. soils in which expression of disease is limited by natural phenomena. It is then of interest to search for the causes of suppressiveness, analyze its mechanisms, and learn how to reproduce or induce suppressiveness in other soils for disease control.

\section{DISEASE SUPPRESSIVENESS IS A BIOLOGICAL PROPERTY OF SOILS}

From a theoretical point of view, soil may be suppressive to disease expression because of its physicochemical or its biological properties. The respective role of biotic and abiotic factors should therefore be clarified before any further study of the mechanisms of disease suppressiveness. This can be achieved by evaluating the effect of the various biocidal treatments (steam, methyl bromide, $\gamma$-rays) on disease suppressiveness (LOUVET et al., 1976; ALABOUVETTE et al., 1977). When disease suppressiveness disappears from the soil due to destruction of living organisms, as has been the case in soils from Châteaurenard, such suppressiveness can be regarded as microbiological (fig. 2).

In general, disease suppressiveness of the soils studied so far is essentially microbiological in nature, i.e. it results from more or less complex microbial interactions, rather than from the direct effect of physicochemical factors on the pathogen. This does not mean that soil physicochemical properties are not involved in the expression of disease suppressiveness. The current state of knowledge, however, does not allow us to evaluate the importance of these properties. Thus, most fusarium-wilt suppressive soils are known to be clay soils with high $\mathrm{pH}(>7)$, but the role of clay type and $\mathrm{pH}$ has not yet been determined. STOTZKY \& MARTIN (1963) established a correlation between the presence of smectite-type clays and the

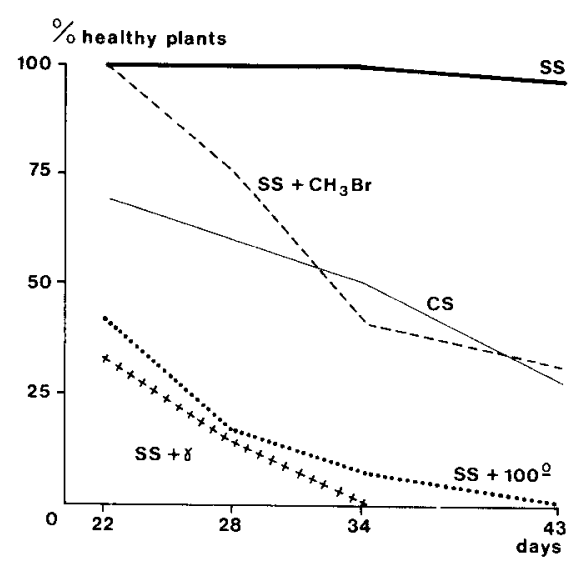

Figure 2

Effects of biocidal treatments on suppressiveness of soil to wilt of muskmelon : percentage of healthy plants after infestation of treated soils with F. o. f. sp. melonis (100 C.F.U./g soil - 18 plants per treatment).

SS : suppressive soil, $\mathrm{CS}$ : conducive soil, $\mathrm{CH}_{3} \mathrm{Br}$ : methyl bromide, $100^{\circ}$ : hot treatment at $100^{\circ} \mathrm{C}, 30 \mathrm{mn}, \gamma: \gamma$ irradiation at 5000 rucks.

Effets de différents traitements biocides sur la résistance du sol à la fusariose vasculaire du melon : pourcentages de plantes saines après infestation des sols traités par F. o. $f$. sp. melonis ( 100 germes $/ g$ sol - 18 plantes/traitement).

$S S:$ sol résistant, $\mathrm{CS}:$ sol sensible, $\mathrm{CH}_{3} \mathrm{Br}$ : bromure de méthyle, $100^{e}$ : traitement à la vapeur à $100{ }^{\circ} \mathrm{C}$ pendant $30 \mathrm{mn}, \gamma$ : irradiation $\gamma$ à la dose de $5000 \$$ rads. 
suppressiveness of soils to fusarium wilt of banana, but the mode of action of these clays remains unknown.

In most cases, as has been found for Châteaurenard soil (fig. 3), disease suppressiveness can be transmitted by simply mixing a small proportion of disease-suppressive soil with some previously heat-treated diseaseconducive soil (LOUVET et al., 1976). Only microorganisms are likely to multiply and confer a high level of suppressiveness to a disease-conducive soil.

After indirectly demonstrating the role of microflora in disease suppressiveness, investigators then try to identify precisely the microorganisms involved.

\section{ROLE OF SPECIFIC MICROFLORA IN DISEASE SUPPRESSIVENESS}

The first objective is to identify within a microflora the antagonistic organisms that induce suppressiveness. Various methods can be used. We chose to eliminate certain components of the microflora selectively by applying steam-air treatments (ROUXEL et al., 1977). After destruction of disease suppressiveness, and of heat-sensitive fungi, we could determine the role of these fungi in the suppression of fusarium wilt (fig. 4). Isolation of the main species of fungi followed by their reintroduction into soil previously heat treated confirmed their individual or collective contribution to the expression of disease suppressiveness (fig. 5). The presence of non-pathogenic Fusarium oxysporum and Fusarium solani was necessary for the expression of disease suppressiveness in the soils from Châteaurenard (fig. 6) (ROUXEL et al., 1979). These soils, as well as other fusarium-wilt

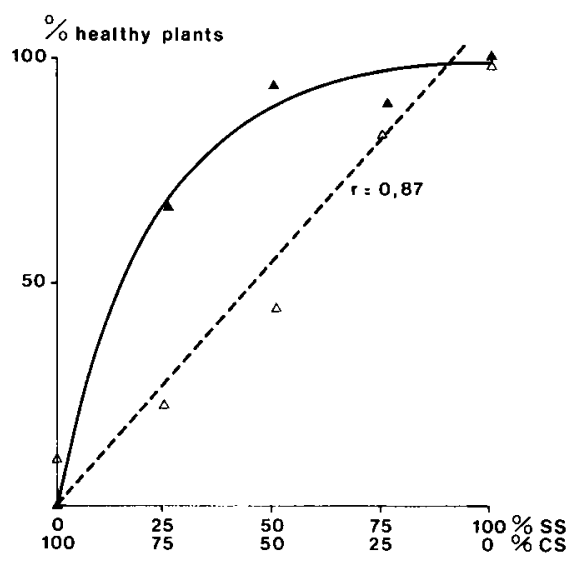

Figure 3

Transmission of suppressiveness from the suppressive soil to a conducive soil, heat-treated (-_-) or non-treated (- - - ) : percentage of healthy plants 8 weeks after planting muskmelons in the mixtures infested with F. o. f. sp. melonis (I00 C.F.U./g soil 18 plants per treatment).

Transmission de la résistance d'un sol résistant à un sol sensible, traité (_- ) ou non traité (- - - -) à la chaleur : pourcentages de plantes saines 8 semaines après culture de melons dans les mélanges infestés par $\mathrm{F}$. o. $f$. $\mathrm{sp}$. melonis $(100$ germes/g sol 18 plantes/traitement).

suppressive soils (TOUSSOUN, 1975), host a large population of indigenous Fusarium species that make up 25 to $40 \%$ of the fungal microflora. An association or relationship apparently exists between the abundance of non-pathogenic Fusarium and wilt suppressiveness.

All fusarium-wilt suppressive soils inhibit the occurrence of all formae speciales of Fusarium oxysporum, but allow the expression of other soil-borne diseases

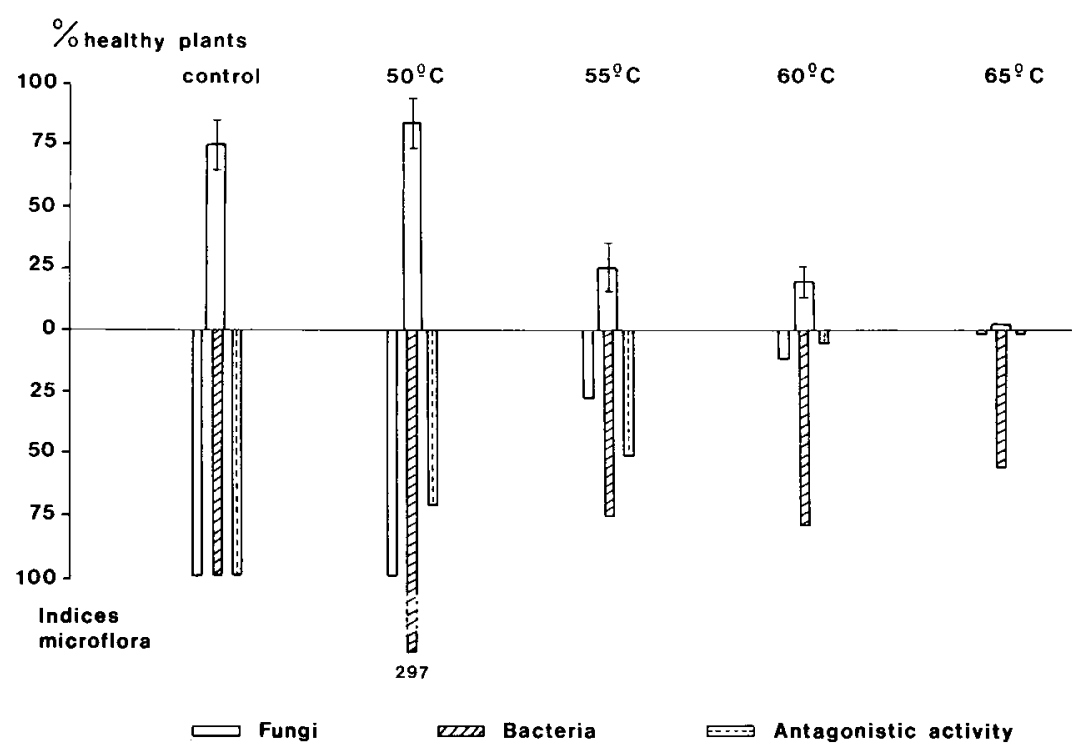

Figure 4

Effects of heat treatments of the suppressive soil on:

- level of microbial populations (indices $100=12.10^{3}$ fungi, $94.10^{5}$ bacteria/g soil) and antagonistic activity of the non-treated control :

- percentage of healthy plants, 3 weeks after planting 116 plants per treatment) in treated, then infested soils with F. o. f. sp. melonis (350 C.F.U./g soil).
Effets de traitements thermiques ménagés du sol résistant sur: - la densité des populations microbiennes (indice $100=12.10^{3}$ champignons, $94.10^{5}$ bactéries/g sol) et activité antagoniste $d u$ témoin non traité ;

- le pourcentage de plantes saines, 3 semaines après plantation (16 plantes/traitement) dans le sol traité puis infesté par F. o. $f$. sp. melonis (350 germes/g sol). 


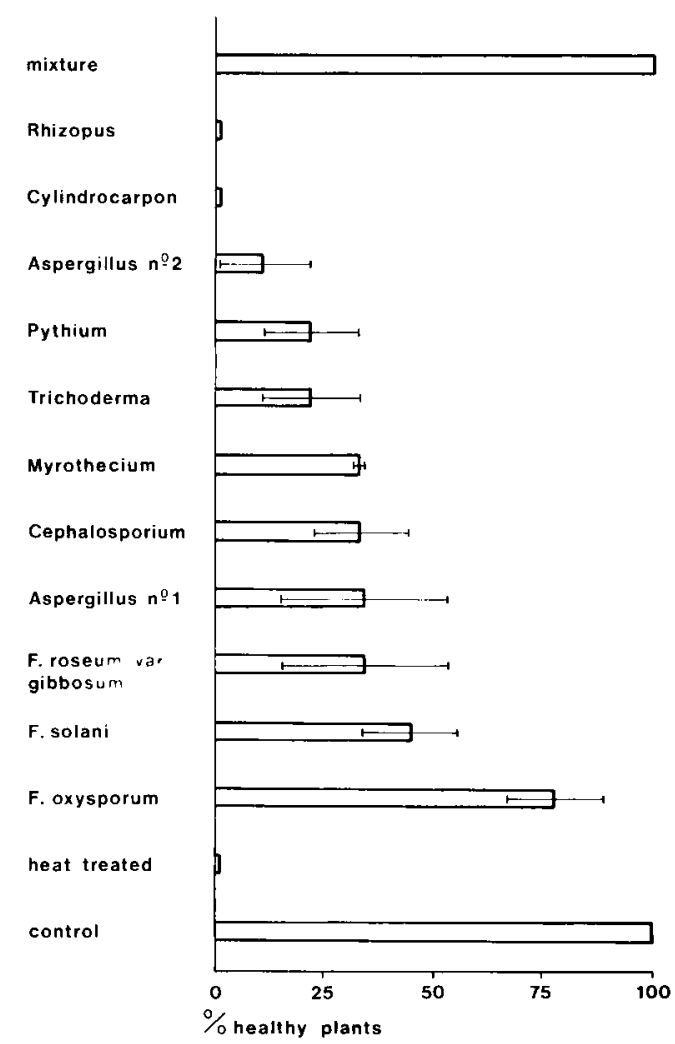

Figure 5

Ability of different fungi isolated from the suppressive soil to reestablish the suppressiveness in steamed suppressive soil; percentage of healthy plants 6 weeks after infestation with F. o.f. sp. melonis (500 C.F.U. g/soil). Mean of 4 replicates of 3 plants with its standard deviation.

Capacité de différentes espèces fongiques isolées du sol résistant à rétablir la résistance préalablement détruite par un traitement à la chaleur ; pourcentage de plantes saines 6 semaines après infestation du sol par F. o. $f$. sp. melonis (500 germes $/ g$ sol). Moyennes de 4 répétitions de 3 plantes avec leurs écarts-type.

(SMITH \& SNYDER, 1972; AlabouvetTE et al., $1980 a$ ). This specific action proves the existence of a particular mechanism which only affects the activity of Fusarium oxysporum that cause vascular wilts.

It may be concluded that suppressiveness of soils from the Châteaurenard region implies the activity of a particular microbial population, of non-pathogenic Fusarium, inimical to the pathogenic Fusarium.

The suppressiveness that results from a particular population of antagonistic microorganisms, refered to as « specific suppression » by COOK \& BAKER (1983), has frequently been described. The microorganisms responsible for this suppression are, like those found in our study, fungi very similar to the pathogen with regard to systematics, ecology and physiology, or they are antagonistic bacteria or actinomycetes.

Once the specific microbial population that causes this suppression has been identified, it is important to study its mode of action. Usually, the suppression observed in situ cannot be explained by an in vitro confrontation between the pathogen and antagonists, such as used to demonstrate antibiosis or hyperparasitism. Except for the mode of action of Trichoderma (DAVET, 1983), most of the antagonisms found to occur in disease-suppressive soils are based on com-

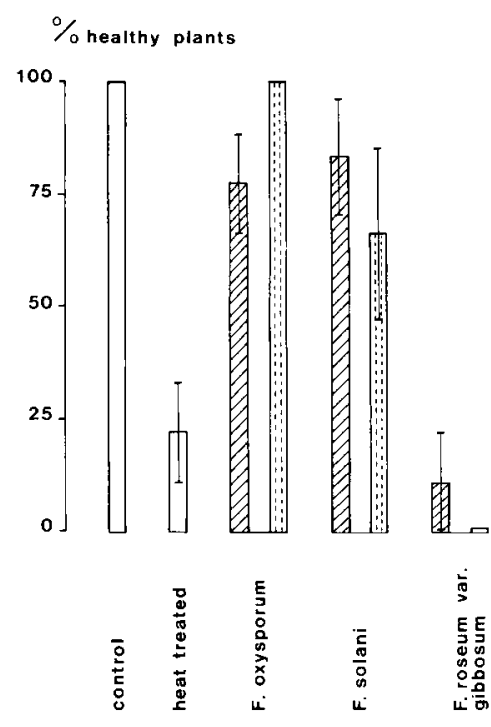

Figure 6

Ability of different strains of Fusarium native ZZZZZA or exotic $\because \because \because \because$ to suppressive soil, introduced at 3000 C.F.U./g soil, to establish suppressiveness in steamed suppressive soil ; percentage of healthy plants 8 weeks after infestation with F. o. $f$. sp. melonis (500 C.F.U./g soil). Mean of 4 replicates of 3 plants with its standard deviation.

Capacité de différentes souches de Fusarium originaires $\square Z Z Z$ ou non $\because \because \because$ du sol résistant, introduites à 3000 germes $/ g$ sol, à rétablir la résistance dans le sol préalablement traité à la chaleur ; pourcentage de plantes saines 8 semaines après infestation par $\mathrm{F}$. 0 . $f$. $s p$. melonis $(500$ germes $/ g$ sol). Moyennes de 4 répétitions de 3 plantes avec leurs écarts-type.

petition for nutrients between microorganisms. It is very difficult, however, to demonstrate experimentally that two microorganisms are in competition for nutrients and to determine the substrate for which they compete in the soil. The immobilization by siderophores of fluorescent Pseudomonas species of iron needed by Fusarium for its development is one of the few known examples of competition for a given trace element (SCHER \& BAKER, 1982).

In the case of intrageneric competition between pathogenic and non-pathogenic Fusarium, we successively considered the various sites in which such competition could occur with sufficient intensity to provide soil suppressiveness.

\section{COMPETITION BETWEEN FUSARIUM SPP IN THE SOIL}

To understand the phenomena of intrageneric competition in the soil between pathogenic and nonpathogenic Fusarium spp., we compared the population dynamics of Fusarium spp. in a suppressive soil from Châteaurenard with that in a conducive soil from Ouroux. We simultaneously observed in both soils the changes in total population of Fusarium spp. and in population of a pathogenic Fusarium oxysporum introduced experimentally at rates of 100 and 1000 propagules per $\mathrm{g}$ of soil. The density of the pathogen population reached comparable levels in both soils, regardless of experimental conditions 
The purpose of our following comparative study of the behaviour of Fusarium spp. in disease-suppressive and disease-conducive soils was to support our hypothesis that competition inhibits saprophytic development of the pathogen in soil.

\section{FUNGISTASIS AND SOIL RECEPTIVITY}

The study of chlamydospore germination of various Fusarium strains clearly indicates fungistasis to be more intense in suppressive than in conducive soils (fig. 8). Considering that heat treatments, which eliminate suppressiveness, nullify fungistasis and allow all chlamydospores to germinate in both suppressive and conducive soils, there may be a relationship between the intensity of fungistasis and the level of soil suppressiveness (ALABOUVETTE et al., $1980 b$ ).

Fusarium spp., whether pathogenic or non-pathogenic, persist in soil as dormant chlamydospores affected by fungistasis. The plant root exudates overcome the effects of fungistasis and stimulate germination of the chlamydospores whose germ-tubes reach the root surface after a certain period of saprophytic development. To simulate the effect of root exudates, we introduced sugars or amino-acids into

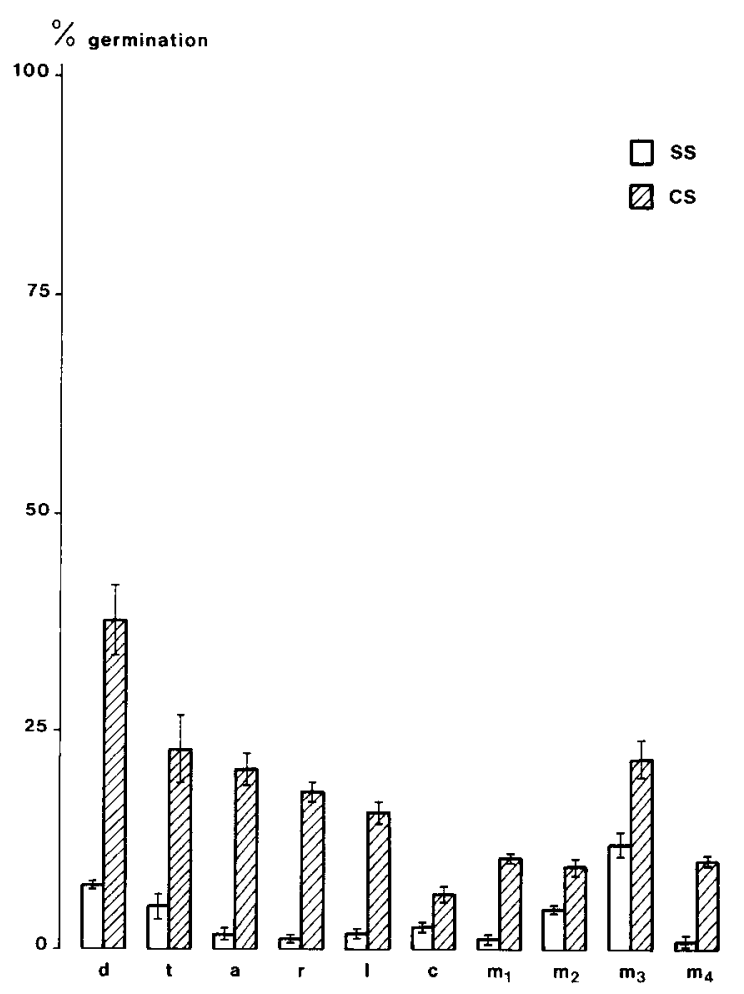

Figure 8

Percentage of germinated chlamydospores of Fusarium oxysporum after $24 h$ of incubation in suppressive or conducive soils $: d=f$. $s p$. dianthi, $t=f$. sp. tulipae, $a=f$. $s p$. albedinis, $r=f$. $s p$. raphani, $l=f$. $s p$. lycopersici, $c=f$. $s p$. cucumerinum ; $m_{l}, m_{2}$, $m_{3}, m_{4}=$ four races of $f$. $s p$. melonis.

Pourcentages de germination des chlamydospores de différentes formes spéciales de F. oxysporum après $24 h$ d'incubation au contact des sols résistants (SS) ou sensible (CS) : $d=f$. sp. dianthi ; $t=f$. $s p$. tulipae ; $a=f$. $s p$. albedinis; $r=f$. $s p$. raphani ; $l=f$. $s p$. lycopersici ; $c=f$. $s p$. cucumerinum ; $m_{l}, m_{2}, m_{3}, m_{4}=4$ races de f. $s p$. melonis. the soils (ALABOUVETTE et al., 1985b). The soils from Châteaurenard were supplied with glucose that stimulates optimal chlamydospore germination (fig. 9). In agreement with the theories of LOCKWOOD (1981), these findings show that fungistasis results from competition for carbon nutrients. These findings show further that fungistasis is more intense in suppressive than in conducive soil since a greater concentration of glucose is needed to produce the same percentage of germinated chlamydospores in suppressive than in conducive soil. We also demonstrated that chlamydospore germination, along with the mycelial growth following germination, depends on competition for nutrients, which is more intense in suppressive soil.

The receptivity of both soils to fusarium wilts thus appears to be correlated with the intensity of competition for carbon. The effect of intrageneric competition between pathogenic and non-pathogenic forms of Fusarium spp. may depend on the general competition for nutrients, the latter intergeneric competition having the stronger effects since it involves

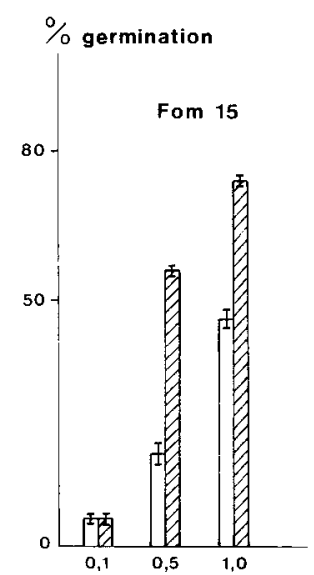

Fod

Fol 8
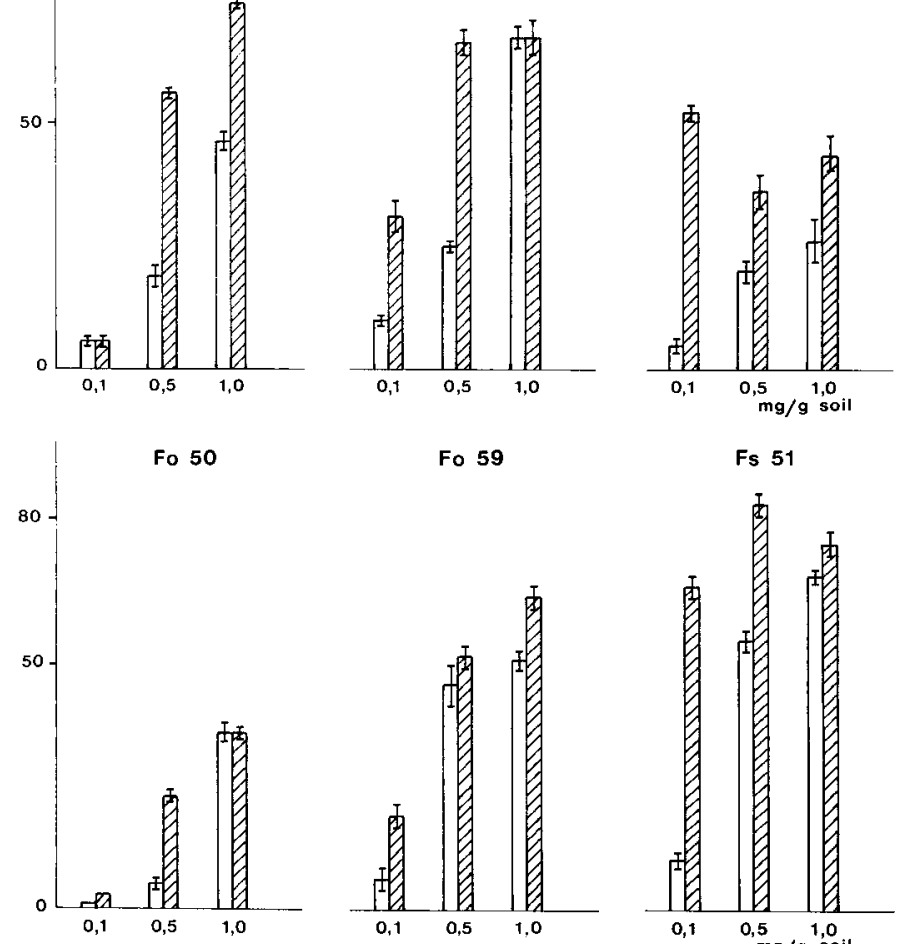

Fo 59

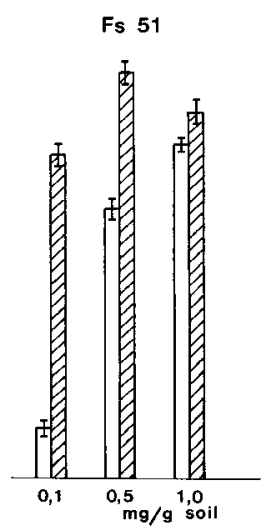

Figure 9

Percentage of germinated chlamydospores after $24 \mathrm{~h}$ of incubation in suppressive (SS) or conducive (CS) soils amended with increasing concentrations of glucose.

Fom $15=$ F. oxysporum $f$. sp. melonis ; Fod $=$ F. oxysporum $f$. $s p$. dianthi $; F o l=\mathrm{F}$. oxysporum $f$. $s p$. lycopersici.

Fo 50 and Fo 59 = non-pathogenic $\mathrm{F}$. oxysporum.

FS 51 : non-pathogenic F. solani.

Pourcentages de chlamydospores germées après $24 h$ d'incubation dans les sols résistant (SS) ou sensible (CS) amendés avec des concentrations croissantes de glucose.

Fom $15=$ F. oxysporum $f$. sp. melonis ; Fod : F. oxysporum $f . s p$. dianthi; $F o l=$ F. oxysporum $f$. sp. lycopersici ; Fo 50 et $F_{O}$ $59=\mathrm{F}$. oxysporum non pathogènes; Fs $51=\mathrm{F}$. solani non pathogène. 
microorganisms with similar nutrient requirements located in the same ecological niche. Pathogen development is very limited in suppressive soil due to the large total Fusarium population, leading to restricted expression of its infectivity.

\section{MICROBIAL BIOMASS, INTENSITY OF NUTRIENT COMPETITION AND SOIL RECEPTIVITY}

Two parameters determine the intensity of competition for a given nutrient : the amount of the nutrient available and the amount (total mass) of microorganisms capable of using this nutrient at the time it becomes available. To evaluate the biomass and total microbial activity of suppressive and conducive soils, we studied their respiratory response to glucose supply (ALABOUVETTE et al., 1985b). It is clear that the initial respiratory rate, which reflects the total microbial biomass (ANDERSON \& DOMSCH, 1978 ), is 3 to 4 times greater in suppressive than in conducive soil (fig. 10). The subsequent respiratory rates also differ in the two soils; carbon dioxide evolution from the suppressive soil increases rapidly, before reaching a peak and then dropping abruptly to a level lower than the initial value after $24 \mathrm{~h}$ incubation ; whereas in conducive soil, the respiratory rate changes less abruptly but is maintained at a higher level after $48 \mathrm{~h}$ incubation. This different behaviour reflects the microbial processes characteristic of the two soils.

The faster and greater initial increase in respiratory rate in suppressive than in conducive soils is related to a larger initial microbial biomass and/or reflects a more active or responsive development of the microorganisms. Either way, the available carbon is quickly depleted and further microbial development is again limited by inadequate nutrients. The more intense the microbial development and activity have been immediately after nutrient supply, the more rapidly the limiting factors appear. Thus, clamydodospores of Fusarium spp., which have a longer lag period than the dormant or latent cells of other microorganisms, are subjected much sooner in suppressive soil than in conducive soil to the nutrient stress resulting from reestablished competition (LOCKWOOD, 1981). Development of Fusarium spp. is stopped before the appearance of significant hyphal growth. In contrast, because conditions remain favourable to microbial development longer in conducive soil, chlamydospore germination and germtube growth occur over a longer period, and the limited nutrient supply results in a significant increase in population density (table 2 ). If we can extrapolate these results to the rhizosphere, as suggested by MANGENOT \& DIEM (1979), the microbial development produced by root exudates is more favourable to Fusarium spp. in conducive soil than it is in suppressive soil, resulting in a higher percentage of successful penetrations.

Thus, the level of soil microbial biomass that determines the intensity of nutrient competition between microbial populations also determines the level of soil receptivity to fusarium wilts.

\section{GENERAL SUPPRESSION AND SPECIFIC SUPPRESSION : TWO COMPLEMENTARY MECHANISMS}

Investigating the microbiological mechanisms of fusarium wilt suppressiveness of soils from Châteaurenard led us to demonstrate the importance of both non-pathogenic Fusarium and the total microbial biomass of the soils. Thus, with reference to

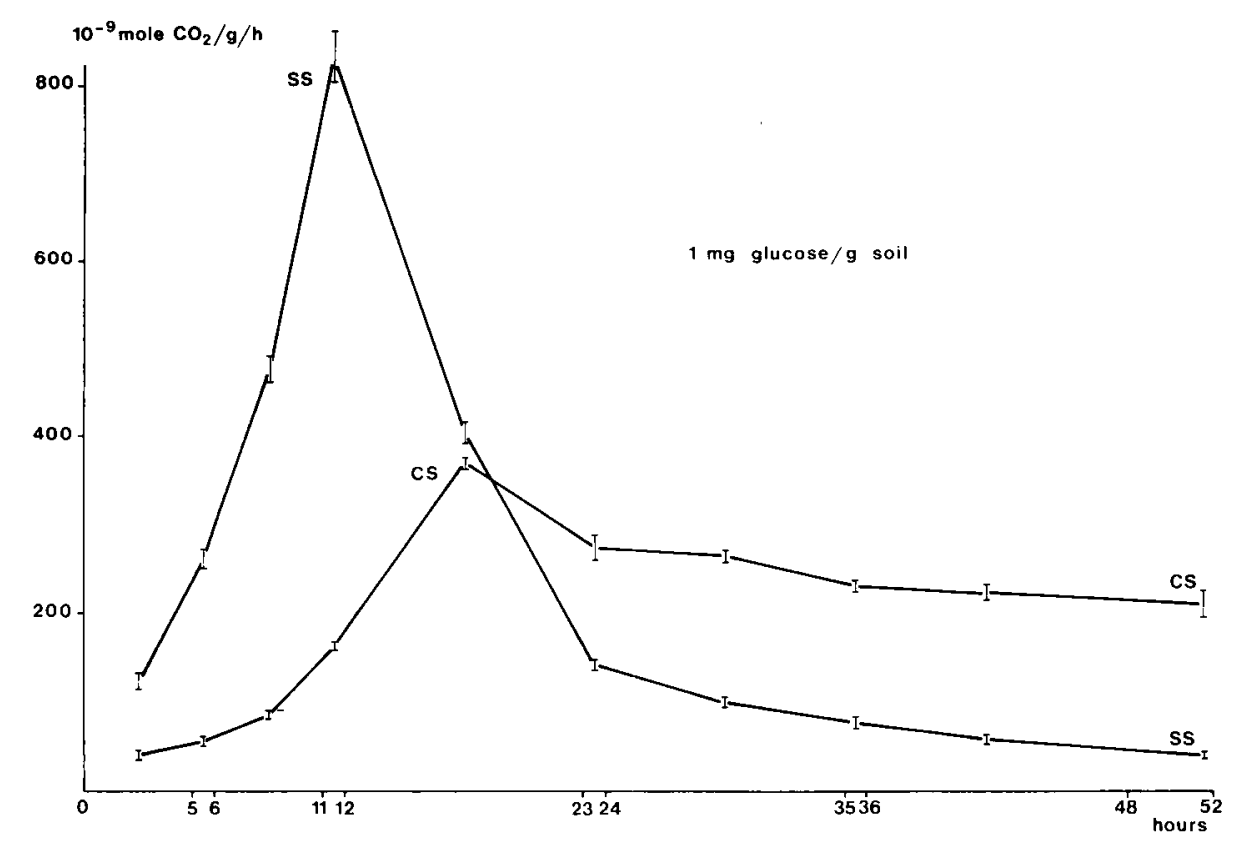

Figure 10

Kinetics of $\mathrm{CO}_{2}$ release from suppressive (SS) and conducive (CS)

Cinétique du dégagement de $\mathrm{CO}_{2}$ par un sol résistant (SS) et un sol soils after addition of $1 \mathrm{mg}$ of glucose $/ \mathrm{g}$ soil. sensible (CS) après addition de glucose (1 $\mathrm{mg} / \mathrm{g}$ sol). 


\section{TABLE 2}

Increase of population densities of Fusarium spp. in suppressive and conducive soils amended with increasing concentrations of glucose; values are the means of 3 analyses made during a period of 2 weeks after addition of glucose and are expressed in percentages compared with the non-treated control.

Evolution des populations de Fusarium spp. dans les sols résistant et sensible amendés avec des doses croissantes de glucose; niveaux moyens des populations enregistrés au cours de 3 analyses successives réalisées 2 semaines après apport du glucose et exprimés en pourcentage du témoin non amendé.

\begin{tabular}{|c|c|c|c|c|c|}
\hline \multirow[b]{2}{*}{ Glucose } & \multicolumn{5}{|c|}{ Suppressive soil } \\
\hline & $\begin{array}{c}\text { Fusarium } \\
\text { spp. }\end{array}$ & $\begin{array}{c}F . \text { oxys- } \\
\text { porum }\end{array}$ & $F$. roseum & F. solani & $\begin{array}{c}\text { F.o. } \\
\text { melonis }\end{array}$ \\
\hline Control & 100 & 100 & 100 & 100 & 100 \\
\hline $0,1 \mathrm{mg} / \mathrm{g}$ & 102 & 92 & 107 & 119 & 100 \\
\hline $0.5 \mathrm{mg} / \mathrm{g}$ & 129 & 117 & 140 & 125 & 194 \\
\hline \multirow[t]{2}{*}{$1 \mathrm{mg} / \mathrm{g}$} & 151 & 130 & 170 & 145 & 138 \\
\hline & \multicolumn{5}{|c|}{ Conducive soil } \\
\hline Control & 100 & 100 & 100 & 100 & 100 \\
\hline $0.1 \mathrm{mg} / \mathrm{g}$ & 156 & 168 & 138 & 136 & 217 \\
\hline $0.5 \mathrm{mg} / \mathrm{g}$ & 286 & 333 & 232 & 260 & 480 \\
\hline $1 \mathrm{mg} / \mathrm{g}$ & 294 & 327 & 225 & 334 & 489 \\
\hline
\end{tabular}

the definitions of COOK \& BAKER (1983), suppression of soils from Châteaurenard may be regarded as both «specific" and "general». Specific suppression refers to the suppressive effect of a specific population of antagonistic microorganisms, whereas general suppression refers to the suppressive effect of a non-specific population, e.g. total soil microbial biomass inhibitory to the pathogen. In take-all of wheat caused by Gaeumannomyces graminis, general suppression is expressed with variable intensity in all soils (GERLACH, 1968). In contrast, specific suppression which develops with wheat monoculture, is possibly associated with take-all decline, and results from the build-up of fluorescent Pseudomonas inhibitory to pathogen development at the root surface (COOK \& BAKER, 1983).

It should be kept in mind that we initially defined the suppressiveness of soils from Châteaurenard as specific to fusarium wilts, indicating that suppression affects only this type of disease. Our definition applies to a specific action, whereas that of COOK \& BAKER (1983), applies to specific mechanisms. If we agree with the latter definition, it appears that the soils from Châteaurenard have both general and specific suppression, indicating that the two mechanisms are complementary rather than opposed. Any specific mechanism of suppression is expressed in soil against a background of general suppression. It is easier, however, to demonstrate the role of a specific antagonistic microbial population than to determine the contribution of the whole microflora acting by means of non-specific competition mechanisms.

Regarding soil receptivity to fusarium wilts, we could provide further evidence of the role of the total microbial biomass by investigating the effect of carbon amendments on the expression of soil suppressiveness or soil conduciveness (ALABOUVETTE et al., 1983). Thus, depending on whether glucose is supplied two weeks before or at the time of soil infestation with the pathogen, the level of soil receptivity either decreases or increases, respectively (fig. 11). In the first case, the supplied energy is used only by the saprophytic microflora which multiplies to a larger biomass more competitive and inhibitory to the development of the pathogen added 2 weeks later. In the second case, the pathogen has the same access to the nutrient supply as the whole microflora and it can infect plants due to the temporary attenuation of nutrient competition. These processes are similar in suppressive and in conducive soil, but they are expressed at different concentrations of added glucose, showing a general mechanism to be involved in relation to the amount and activity of the soil microflora.

\section{TRANSFERRABILITY OF SUPPRESSIVENESS, A PROPERTY WHICH NEEDS TO BE BETTER UNDERSTOOD}

Fusarium-wilt suppressiveness of soils from Châteaurenard relies on the complementary association of a general mechanism of nutrient competition between the whole soil microflora and the entire Fusarium population, and a specific mechanism of intrageneric competition between pathogenic and nonpathogenic Fusarium. Although these mechanisms account for the major part of our experimental observations, they do not adequately explain the fact that suppressiveness can be established by simply mixing a small amount of suppressive soil with a previously heat-treated conducive soil.

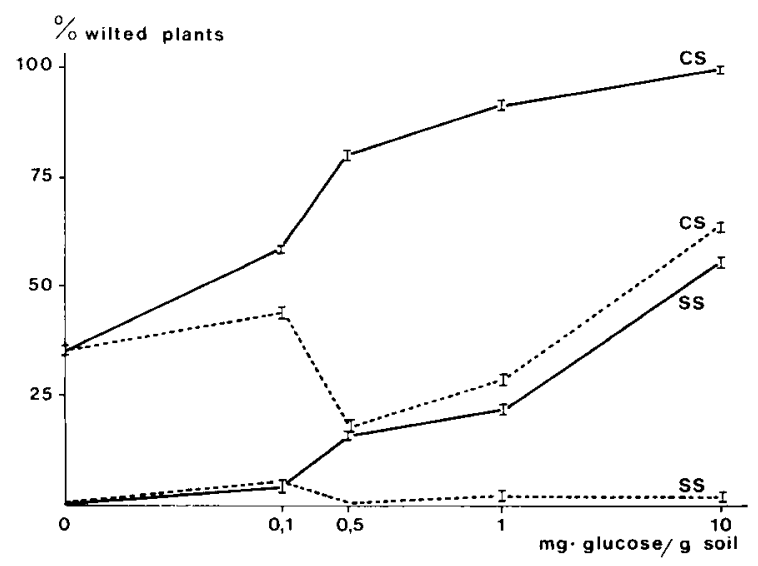

Figure 11

Modifications of soil receptivity to fusarium wilt induced by glucose amendments in suppressive (SS) and conducive (CS) soils.

glucose amendment of soils simultaneously infested with 2500 C.F.U. of F.o. f. sp. lini $/ g$ soil.

-- soils infested with 2500 C.F.U. of F.o. f. sp. lini/g soil two weeks after glucose amendment.

Percentage of wilted plants after 8 weeks of cultivation. Mean of 6 replicates of 10 plants with its standard deviation.

Modifications du niveau de réceptivité des sols résistants (SS) et sensible (CS) induites par apport de glucose.

apport de glucose et infestation simultanée des sols par F.o f. sp. lini à la dose de 2500 germes/g sol.

--- infestation des sols par F. o. f. sp. lini à la dose de 2500 germes $/ g$ sol, 2 semaines après apport du glucose.

Pourcentages de plantes mortes 8 semaines après le semis. Moyenne de 6 répétitions de 10 plantes avec leurs écarts-type. 
It seems difficult to ascribe a major role to general competition for nutrients in this case, since the competition is likely to be as intense as that of the initial conducive soil. The suppressiveness transferred would thus mainly rely on the activity of an antagonistic microbial population that would preferentially colonize the heat-treated conducive soil. This is the prevailing opinion (SCHER \& BAKER, 1980). To our knowledge, however, no clear evidence has been given that the suppressiveness conferred by mixing was due to recolonization of the disinfested soil by a dominant antagonistic population. In our studies, microbiological analyses carried out with suppressive mixtures did not prove the presence of a significant non-pathogenic Fusarium population. Suppressiveness transmission therefore involves microbiological processes that have not yet been elucidated.

One of our current research objectives is to analyze in more detail the microflora associated with plant roots. By successive dilutions, we could confer suppressiveness to a mixture containing only $1 \mathrm{ppm}(\mathrm{v} / \mathrm{v})$ suppressive soil, provided that the intermediate mixtures had been cultivated over the 3-month incubation period between successive dilutions. Analysis of the rhizosphere and rhizoplane bacterioflora may then show the presence of a specific population of microorganisms antagonistic to Fusarium. Our observations can be compared to the results of SCHER \& BAKER (1982) who ascribe to fluorescent Pseudomonas species that colonize the plant rhizosphere a fundamental role in the fusarium-wilt suppressiveness mechanisms of soils from the Salinas Valley.

In any case, the suppressiveness conferred by a mixture is based on microbiological mechanisms other than those already demonstrated in soil from Châteaurenard. Obviously, not all the populations and microbial mechanisms involved in fusarium-wilt suppressiveness of this soil have been discovered yet. Such a powerful and stable suppressiveness is likely to result from the association of various microbial processes that act simultaneously, successively, or independently of each other according to environmental conditions. Experimentally, suppressiveness can be conferred to a disinfested soil by favouring only one mechanism, the resulting suppressiveness not being necessarily the same as the initial one. It may be hoped, however, that by exploitation of the factors of soil suppressiveness, effective biocontrol procedures can be developed.

\section{SUPPRESSIVENESS OF SOILS AND MICROBIOLOGICAL CONTROL OF PLANT DISEASES}

Due to the possibility of transferring suppressiveness from one soil to another, it seemed apparent that microbiological control procedures could be rapidly developed (ALABOUVETTE et al., 1980c). It must be admitted, however, that applications or even large-scale trials have rarely been carried out. This shows how difficult it is to move from the theoretical study of suppressiveness to practical applications for control purposes. In general, two different approaches are chosen : the first method is to use the transfer of suppressive soil, while the second is to introduce into the conducive soil antagonistic microorganisms isolated from the suppressive soil.

Theoretically, the approach using whole soil has one major advantage ; its aim is to use all the microorganisms from the suppressive soil to direct the recolonization of a disinfected soil and hence to reproduce all the microbial interactions involved in suppressiveness. However, complex microbial populations cannot be established outside the suppressive soil in which they occur, and one cannot consider treating large areas by supplying suppressive soil. The possible application of soil from Châteaurenard for protection of horticultural crops growing in various substrates (peat, rock wool, pouzzolane) was considered (COUTEAUdiER \& AlabouvetTe, 1981). The level of suppressiveness conferred to a peat amended with $10 \%(\mathrm{v} / \mathrm{v})$ suppressive soil was close to the suppressiveness of the initial suppressive soil (fig. 12). This procedure is still effective if the percentage of suppressive soil drops to $2 \%$ or even $1 \%$ of the volume of the substrate.

The use of suppressive soil directly has the serious disadvantage that undesirable microorganisms pathogenic to the crop may be introduced into the substrate mixture. To avoid this, we made an artificial and pathogen-free suppressive soil in the laboratory:

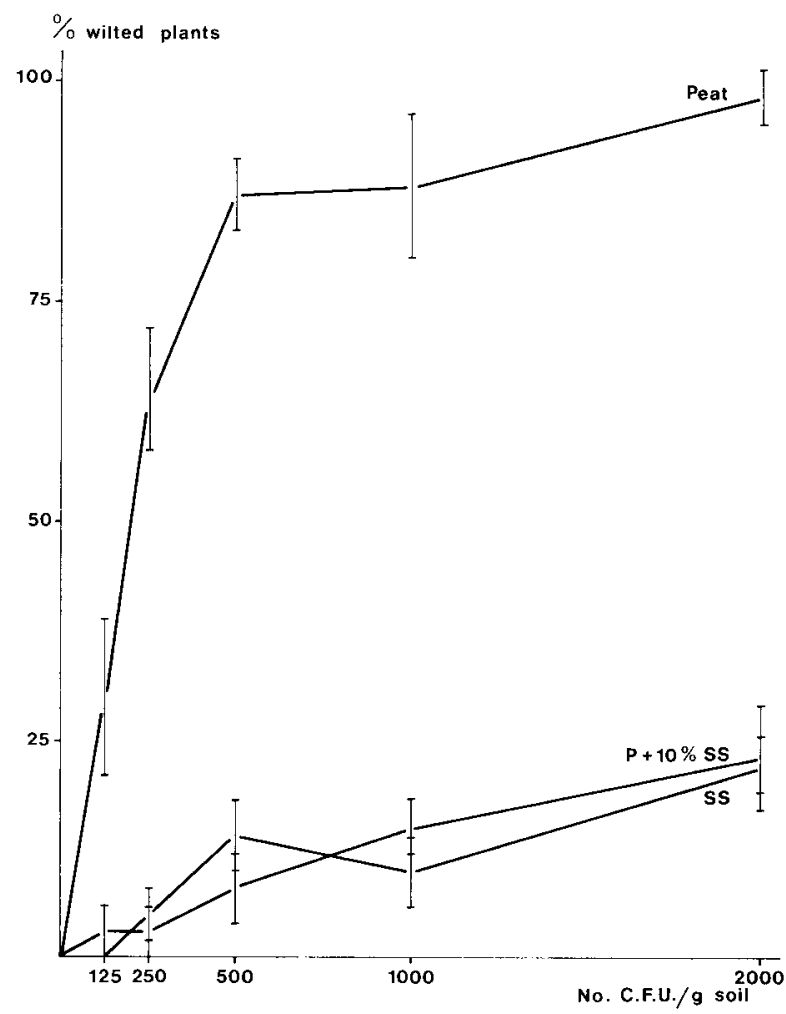

Figure 12

Decrease of fusarium wilt receptivity of a peat $(P)$ amended with $10 \%$ suppressive soil (SS); percentage of wilted plants 6 weeks after peat infestation with F.o. $f$. sp. lini at increasing concentrations. Mean of 8 replicates of 5 plants with its standard deviation.

Diminution du niveau de réceptivité d'un substrat tourbeux amendé avec $10 \%$ de sol résistant; pourcentages de plantes malades 6 semaines après infestation des substrats avec des doses croissantes de F. o. f. sp. lini. Moyennes de 8 répétitions de 5 plantes avec leurs écarts-type. 
microorganisms non-pathogenic to the crops to be protected were isolated from the suppressive soil and introduced into the same soil that had been heattreated $\left(70^{\circ} \mathrm{C}, 30 \mathrm{mn}\right)$. The results of an experiment conducted with this purified suppressive soil under normal conditions of greenhouse tomato cropping (COUTEAUDIER et al., 1985) clearly indicate that a single introduction of $8 \%(\mathrm{v} / \mathrm{v})$ of such a soil produces effective control of fusarium wilt for 3 consecutive years (table 3 ).

The total transfer of soil suppressiveness is therefore an effective and durable control method. To make this procedure suitable for large-scale application, it is necessary to develop a substrate for the transfer of suppressiveness, different of soil itself, compatible with the usual cultural practices, and supporting activity of the useful microorganisms for expression of suppressiveness or even allowing their multiplication.

The second method, which is the more commonly used by pathologists, is to identify an antagonistic microbial population involved in the suppression mechanisms, and then isolate and multiply in vitro these microorganisms and reintroduce them massively into the soil where needed. After demonstrating the role of non-pathogenic Fusarium oxysporum and Fusarium solani in the suppression mechanisms of soils from Châteaurenard, we tried to use them for controlling fusarium wilts. Following several tests under controlled conditions, we demonstrated under normal cropping conditions that peat enriched in non-pathogenic Fusarium mixed to a naturally infested soil after steaming could significantly limit disease severity (table 3). These results can be improved by selecting among these non-pathogenic Fusarium the strains that are best capable of colonizing the soil and competing with the pathogen.

The selection of antagonistic strains is one of the most difficult problems to overcome, regardless of the organism. The reason is that biological experimentation in normal growing conditions, which is the only method of evaluating thoroughly the capacity of a strain to protect a crop by integrating all its properties, is tedious and does not allow the simultaneous comparison of many different strains. It is therefore necessary to determine selection criteria that can be studied in vitro and actually account for the antagonistic properties of strains under biological control conditions. Identification of the parameters to be considered justifies the conducting of a preliminary test as the mechanism of action of the antagonist is identified.

With non-pathogenic Fusarium, we indicated that intrageneric competition could occur either in the soil or at the plant root surface. The capacity of various non-pathogenic Fusarium strains to colonize the soil and root cortex were therefore compared. The initial results obtained indicate clear differences in behaviour in relation to the capacity of strains to protect a crop.

In addition to this screening work, attempts have been made to optimize mass production of these nonpathogenic Fusarium and to test the various modes of application compatible with cultural techniques. The preliminary steps to practical application should be easily achieved as Fusarium species are easy to cultivate on various substrates and to store. We shall try
TABLE 3

Incidence of fusarium wilt of tomatoes after different soil treatments in a greenhouse soil naturally infested with Fusarium oxyspo$\operatorname{rum} f$. sp. lycopersici.

Gravité de la fusariose vasculaire de la tomate après différents traitements du sol dans une serre naturellement infestée par F.o. f. sp. lycopersici.

$A$ : non treated plot; parcelle témoin.

B : plot steam-treated for $12 \mathrm{~h}$ in July 1981 ; parcelle traitée $12 \mathrm{~h}$ à la vapeur en juillet 1981

$C:$ plot steam-treated as plot $B$ and then amended with a pathogenfree suppressive soil at a rate of $8 \%$ to a depth of $20 \mathrm{~cm}$; parcelle traitée de façon identique à la parcelle $B$ puis amendée avec du sol résistant épuré $(8 \%)$ en volume sur $20 \mathrm{~cm}$ de profondeur.

$D:$ plot steam-treated before introduction of non pathogenic Fusarium (1983); parcelle traitée à la vapeur en juillet 1983 avant apport de Fusarium antagonistes. 64 plants/plot $\left(25 \mathrm{~m}^{2}\right) ; 64$ plantes par parcelle $\left(25 \mathrm{~m}^{2}\right)$.

Disease incidence

\begin{tabular}{ccccccc}
\hline Plots & \multicolumn{2}{c}{1981} & \multicolumn{2}{c}{1982} & \multicolumn{2}{c}{1983} \\
& (a) & (b) & (a) & (b) & (a) & (b) \\
\hline A & 42 & 31 & 83 & 54 & \multicolumn{2}{c}{-} \\
\hline B & 55 & 48 & 89 & 72 & 98 & 91 \\
\hline C & 6 & 2 & 11 & 4 & 25 & 17 \\
\hline D & & & & & 20 & 15 \\
\hline
\end{tabular}

(a) Percentage of diseased plants ; (b) cumulative index of disease severity 20 weeks after planting evaluated on a $0-5$ scale (0 healthy, 1 yellowing of 1 leaf, 2 yellowing of 2-3 leaves, 3 yellowing of several leaves, 4 wilting, 5 dead plant)

(a) Pourcentages de plantes infectées ; (b) indice de flétrissement 4 mois et demi après plantation, évalué sur une échelle de 0 à 5 ( 0 : plante saine, 1 : jaunissement d'une feuille, 2 : jaunissement de 2 à 3 feuilles, 3 : jaunissement de plusieurs feuilles, 4 : flétrissement, 5 : plante morte).

to commercialize this control method in cooperation with industrial companies capable of multiplying strains and professional organizations in charge of field development and testing.

\section{DISCUSSION}

This review of 10 years of research work devoted to fusarium-wilt suppressive soils from Châteaurenard shows the complexity but also the significance of such studies. Analyzing the mechanisms of soil suppressiveness appears to be a logical line of research for the study of microbial interactions in soil. Considerable progress has been made in understanding the microbiological mechanisms that account for soil suppressiveness.

However, not all the microbial processes conferring certain suppressiveness properties such as transferrability have been determined. Also, some fundamental questions pertaining to the reason for the abundance of Fusarium spp. in fusarium-wilt suppressive soils or to the effects of abiotic factors on microbial interactions have not been answered. Although the existence of interactions between physicochemical and microbiological properties of soils, especially their level of receptivity to disease, could not be clearly demonstrated, it must be admitted that pedological 
and cultural soil characteristics as well as the soil history participate in determining the balance between the various populations of soil microorganisms (TRAMIER et al., 1979). Study of disease-suppressive soils could allow us to understand this problem better, as a clear correlation is sometimes found between a given soil type and suppressiveness to a given disease (STUTZ \& DEFAGO, 1983).

The concept of soil receptivity to disease was coined during research on soil suppressiveness. Receptivity appears to be a fundamental property of soils and to be related to both their biotic and abiotic properties. Receptivity represents all the general and specific activities of the microflora in the presence of a given pathogen. In fact, any natural soil has some potential for suppressiveness, i.e. a capacity to limit the expression of pathogens. Yet, this concept of receptivity is more general. It also applies to the microorganisms beneficial to crops, and which are naturally present in the soil or artificially introduced for disease control or enhanced plant growth. Successful microbiological control procedures based on the introduction of an antagonistic microbial population into the soil will largely depend on the receptivity of this soil to the antagonist. Procedures should take into account the soil physicochemical and microbiological characteristics.

It should be noted that it is the study of pathogensuppressive soils that helped to isolate all the antagonistic microorganisms, except Trichoderma spp., currently evaluated for use in the biological control of soilborne pathogens. Thus, several recent publications report biological control tests against fusarium wilts by use of non-pathogenic Fusarium spp. (TRAMIER et al., 1983). Due to the promising results obtained, we will accelerate our program for screening protective strains, make further investigations into the interrelationships between pathogenic and non-pathogenic Fusarium, and use mathematical models to study intrageneric competition for soil or substrate colonization. The efficacy of competition between pathogenic and non-pathogenic forms of Fusarium oxysporum, i.e. between related strains which belong to the same species and cannot be differentiated on the basis of morphological or biochemical criteria, raises questions concerning variability within the species and determinants of pathogenicity in Fusarium oxysporum. This research on fusarium-wilt suppressiveness of soils should therefore not be limited to the study of microbial interactions in soils, but should be expanded to include investigations into the genetics of Fusarium oxysporum.

Reçu le 29 juillet 1985. Accepté le 5 novembre 1985.

\section{ACKNOWLEDGMENT}

The author is deeply grateful to R. Y. COOK for reviewing the manuscript.

\section{RÉFÉRENCES BIBLIOGRAPHIQUES}

\begin{abstract}
Alabouvette C., Rouxel F., Louvet J., 1977. Recherches sur la résistance des sols aux maladies. III. Effets du rayonnement $\alpha$ sur la microflore d'un sol et sa résistance à la fusariose vasculaire du melon. Ann. Phytopathol., 9, 467-471.
\end{abstract}

Alabouvette C., Rouxel F., Louvet J., 1979. Characteristics of fusarium-wilt suppressive soils and prospects for their utilization in biological control, 165-182. In : B. Schippers, W. Gams : "SoilBorne Plant Pathogens". Academic Press, 686 p.

Alabouvette C., Rouxel F., Louvet J., 1980a. Recherches sur la résistance des sols aux maladies. VI. Mise en évidence de la spécificité de la résistance d'un sol vis-à-vis des fusarioses vasculaires. Ann. Phytopathol., 12 (1), 11-19.

Alabouvette C., Rouxel F., Louvet J., 1980b. Recherches sur la résistance des sols aux maladies. VII. Etude comparative de la germination des chlamydospores de Fusarium oxysporum et Fusarium solani au contact de sols résistants et sensibles aux fusarioses vasculaires. Ann. Phytopathol., 12 (1), 21-30.

Alabouvette C., Tramier R., Grouet Denise, 1980c. Recherches sur la résistance des sols aux maladies. VIII. Perspectives d'utilisation de la résistance des sols pour lutter contre les fusarioses. Ann. Phytopathol., 12 (2), 83-93.

Alabouvette C., Couteaudier Y., Louvet J., 1982. Comparaison de la réceptivité de différents sols et substrats de culture aux fusarioses vasculaires. Agronomie, 2 (1), 1-6.

Alabouvette C., Couteaudier Y., Louvet J., 1983. Importance des phénomènes de compétition nutritive dans l'antagonisme entre microorganismes, 7-16. In: "Les antagonismes microbiens. Modes d'action et application à la lutte biologique contre les maladies des plantes ». 24e Coll. Soc. fr. Phytopathol., Bordeaux, 26-28 mai $1983,360 \mathrm{p}$.

Alabouvette C., Couteaudier Y., Louvet J., 1984a. Recherches sur la résistance des sols aux maladies. IX. Dynamique des populations de Fusarium spp. et de Fusarium oxysporum f. sp. melonis dans un sol résistant et un sol sensible aux fusarioses vasculaires. Agronomie, 4 (8), 729-733.
Alabouvette C., Couteaudier Y., Louvet J., 1984b. Recherches sur la résistance des sols aux maladies. X. Comparaison de la mycoflore colonisant les racines de melons cultivés dans un sol résistant ou un sol sensible aux fusarioses vasculaires. Agronomie, 4 (8), 735-740.

Alabouvette C., Couteaudier Y., Louvet J., 1985a. Fusarium-wilt suppressive soils : mechanisms of suppression and management of suppresiveness, 101-106. In : C. A. Parker, D. J. Moore, P. T. W. Wong, A. D. Rovira \& J. F. Kollmorgen : "Ecology and Management of Soil Borne Plant Pathogens". Am. Phytopathol. Soc., St Paul MN, 358 p.

Alabouvette C., Couteaudier Y., Louvet J., 1985b. Recherches sur la résistance des sols aux maladies. XI. Etude comparative du comportement des Fusarium spp. dans un sol résistant et un sol sensible aux fusarioses vasculaires enrichis en glucose. Agronomie, 5 (1), 63-68.

Alabouvette C., Couteaudier Y., Louvet J., 1985c. Recherches sur la résistance des sols aux maladies. XII. Activité respiratoire dans un sol résistant et un sol sensible aux fusarioses vasculaires enrichis en glucose. Agronomie, 5 (1), 69-72.

Anderson J. P. E., Domsch K. H., 1978. A physiological method for the quantitative measurement of microbial biomass in soils. Soil Biol. Biochem., 10, 215-221.

Cook R. J., Baker K. F., 1983. The nature and practice of biological control of plant pathogens. Am. Phytopathol. Soc., St Paul MN, USA, $539 \mathrm{p}$.

Couteaudier Y., Alabouvette C., 1981. Fusarium wilt diseases in soilless cultures. Acta Horticulturae, Substrates in Horticulture, 126, 153-157.

Couteaudier Y., Letard M., Alabouvette C., Louvet J., 1985. Lutte biologique contre la fusariose vasculaire de la tomate. Résultats en serre de production. Agronomie, 5 (2), 151-156.

Davet P., 1983. Les Trichoderma. Exemple de champignons antagonistes d'agents pathogènes, 193-205. In : " Faune et flore auxiliaires en agriculture ». Journées d'études et d'informations, ACTA, Paris, 4 et 5 mai 1983, 367 p. 
Gerlach W., 1968. Introduction of Ophiobolus graminis into new polders and its decline. Neth. J. Plant Pathol., 74 (suppl. 2), 1-97. Lockwood J. L., 1981. Exploitation competition, 319-350. In : D. T. Wicklow \& G. C. Carrol : "The fungal community. Its organization and role in the ecosystem', M. Dekker, Inc, 833 p.

Louvet J., Alabouvette C., Rouxel F., 1981. Microbiological suppressiveness of some soils to fusarium wilts, 261-275. In : P. F. Nelson, T. A. Toussoun, R. J. Cook : "Fusarium : Diseases, Biology and Taxonomy". The Pennsylvania State University Press, $457 \mathrm{p}$.

Louvet J., Rouxel F., Alabouvette C., 1976. Recherches sur la résistance des sols aux maladies. I. Mise en évidence de la nature microbiologique de la résistance d'un sol au développement de la fusariose vasculaire du melon. Ann. Phytopathol., 8, 425-436.

Mangenot F., Diem H. G., 1979. Fundamentals of biological control, 207-265. In : S. V. Krupa, Y. R. Dommergues : "Ecology of root pathogens". Elsevier, 281 p.

Rouxel F., Alabouvette C., Louvet J., 1977. Recherches sur la résistance des sols aux maladies. II. Incidence de traitements thermiques sur la résistance d'un sol à la fusariose vasculaire du melon. Ann. Phytopathol., 9, 183-192.

Rouxel F., Alabouvette C., Louvet J., 1979. Recherches sur la résistance des sols aux maladies. IV. Mise en évidence du rôle des Fusarium autochtones dans la résistance d'un sol à la fusariose vasculaire du melon. Ann. Phytopathol., 11, 199-207.

Scher M. F., Baker R., 1980. Mechanisms of biological control in a Fusarium suppressive soil. Phytopathology, 70, 412-417.

Scher M. F., Baker R., 1982. Effects of Pseudomonas putida and synthetic iron chelator on induction of soil suppressiveness to Fusarium wilt pathogens. Phytopathology, 72, 1567-1573.
Schneider R. W., 1982. Suppressive soils and plant disease. Am. Phytopathol. Soc., St Paul MN, USA, 87 p.

Schneider R. W., 1984. Effects of non-pathogenic strains of Fusa rium oxysporum on celery root. Infection by Fusarium oxysporum t. sp. apii and a novel use of the Lineweaver Burk double reciprocal plot technique. Phytopathology, 74, 646-653.

Smith S. N., Snyder W. C., 1972. Germination of Fusarium oxysporum in soils favourable and unfavourable to wilt establishment. Phytopathology, 62, 273-277.

Stotzky G., Martin R. T., 1983. Soil mineralogy in relation to the spread of fusarium wilt of banana in Central Africa. Plant Soil, 18, 317-338.

Stutz E. W., Defago G., Hantke R., Kern H., 1985. Effect of parent materials derived from different geological strata on suppressiveness of soils to black root rot of tobacco, 215-217. In : C. A. Parker, D. J. Moore, P. T. W. Wong, A. D. Rovira \& J. F. Kollmorgen : «Ecology and management of soil borne plant pathogens. Ann. Phyto. pathol. Soc., St Paul MN, 358 p.

Toussoun T. A., 1975. Fusarium-suppressive soils, 145-151. In : G. W. Bruehl : "Biology and control of soil-borne plant pathogens". Am. Phytopathol. Soc., 217 p.

Tramier R., Pionnat J. C., Bettachini A., Antonini C., 1979. Recherches sur la résistance des sols aux maladies. V. Evolution de la fusariose vasculaire de l'œillet en fonction des substrats de culture. Ann. Phytopathol., 11 (4), 477-482.

Tramier R., Pionnat J. C.. Tebibel N., 1983. Role of the fungi in the induction of suppressiveness into substrates of lusarium wilt of carnation. Acta Hortic., 141, 55-59. 